\title{
Analysis of Force Conditions of the Hot Forming Machine in Rolling-Out of Bearing Rings
}

Marián Handrik, Milan Sága, Peter Pecháč, Peter Kopas

Faculty of applied mechanics University of Žilina, Univerzitná 1, Žilina 010 26, Slovak Republic, E-mail: marian.handrik@fstroj.uniza.sk,milan.saga@fstroj.uniza.sk, peter.pechac@fstroj.uniza.sk, peter.kopas@fstroj.uniza.sk.

The main parameters of the hot forming machines are production capacity and the fatigue life of the used tools. The life of a tool depends on its shape and load. The load depends on the structural design and speed of forming. The goal of our paper is to present the structural optimization and technological parameters design with respect to tool life. This process is applied in the case of the hot forming machine analysis.

Keywords: Design, Optimizing Process, Hot Forming, Tool Life

\section{Acknowledgements}

This work has been supported by grant project VEGA No. 1/0234/13.

\section{References}

[1] VASILKO, K. a kol. (1988). Valivé ložiská. ALFA Bratislava.

[2] ŽMINDÁK, M., MELICHER, R., MAZÚR, J. (2005). Modelovanie cyklickej plasticity použitím MKP, Výpočty Jednodenní seminář, 24.11.2005 Plzeň, pp. 65-76.

[3] ZMINDAK, M., RADZISZEWSKI, L., PELAGIC, Z., FALAT, M. (2005). FEM/BEM Techniques for Modelling of Local Fields in Contact Mechanics. Communications 3/2005, pp 37-45.

[4] ŽÍDEK, M., DĚDEK, V., SOMMER, B. (1988). Tvárení oceli. SNTL Praha.

[5] SKOČOVSKÝ, P., VAŠKO, A. (2004). Materiály a technológie. 1. vyd. EDIS, Žilina, pp. 122.

[6] SÁGA, M., VAVRO, J., KOPECKÝ, M. (2003). Počítačová analýza a syntéza mechanických sústav, ZUSI Žiline.

[7] NOVÁK P., ŽMINDÁK, M., PELAGIĆ, Z. (2014). High-Pressure Pipelines Repaired by Steel Sleeve and Epoxy Composition. Applied Mechanics and Materials Vol. 486, pp 181-18.

[8] RADZISZEWSKI L. (2003). The influence of the surface load exerted by a piezoelectric contact sensor on testing results: Part I, The displacement field in the solid, Archives of Acoustics 28, pp 71 - 91.

[9] SAPIETOVÁ, A., LUKÁČ, M. (2014). The impact analysis of a tire model properties on running stability of a vehicle inthe environment of ADAMS/Car. In: Applied Mechanics and Materials - Novel Trends in Production Devices and Systems II, NTPDS II; Vol. 693, pp. 165-170, ISSN 1660-9336

[10]JAKUBOVIČOVÁ, L., SÁGA, M. (2014). Computational analysis of contact stress distribution in the case of mutual slewing ofroller bearing rings. In: Applied Mechanics and Materials - Novel Trends in Production Devices and Systems, NTPDS 2014; Vol. 474, pp. 363-368, ISSN 1660-9336

[11]SÁGA, M., VAŠKO, M., KOPAS, P., JAKUBOVIČOVÁ, L. (2014). Numerical algorithm for beam residual stress identification. In: Comunications, Vol 16, No. 3A, pp. 13-18, ISSN 1335-4205

[12]DEKÝŠ, V., SAPIETOVÁ, A., ŠTEVKA, O. (2014). Understanding of the dynamical properties of machines based on the interpretation of spectral measurements and FRF. In: Applied Mechanics and Materials - 51st Annual of the International Scientific Conference on Experimental Stress Analysis, EAN 2013; Litomerice; Czech Republic; 11 June, Vol. 486, 2014, pp. 106-112, ISSN 1660-9336 